\title{
A Preliminary Electron Microscopic Investigation of the Compound Eye of The Ghost Crab, Ocypode platytarsus
}

\author{
T. A.Ba-Omar*, I. Al-Aamri** and D.A. Clayton* \\ *Biology Department, College of Science, Sultan Qaboos University, PO Box 36, Muscat \\ 123, Sultanate of Oman \\ ** Pathology Department, College of Medicince and Health Sciences, Sultan Qaboos \\ University, PO Box 35, Muscat 123, Sultanate of Oman
}

It is generally accepted that the phenomenon of eyestalks and horizontally aligned acute zones in the apposition compound eye of Ocypodids is an adaptation to living in a flat, featureless habitat such as a mud or sand flat [1]. Studies were conducted on species from several families and genera, but within the Ocypode genus, species can be variously found from the supratidal to the low intertidal zone, providing for a closer comparative study than has hitherto been the case. In Oman there are five sympatric species of Ocypode ghost crabs and this study represents the start of a full comparative study.

Ghost crabs Ocypode platytarsus were collected and brought into the Biology Department laboratory where the animal were killed by mean of freezing the animals. The eyes were dissected out and fixed in Karnovsky and postfixed in 1\% osmiun tetraxide $\left(\mathrm{OsO}_{4}\right)$. The tissues were processed for SEM. Samples were placed in the SEM (JEOL 5600 LV-low vacuum).

While the acute zones have been mapped in O. ceratopthalmus [2], electron microscopic investigations have concerned O. cursor [3] and O. ryderi [4]. Here we report on a scanning study of Ocypode platytarsus. As in Uca [5], it is likely that facets are larger, and crystalline cones and rhabdoms in the equatorial part of the eyes, are longer than in the dorsal and ventral parts of the eyes [Fig. 1a,b,c].

[1] J. Zeil et al., In R.N. Singh and N.J. Strausfeld, Neurobiology of Sensory Systems, Plenum, (1989), 123.

[2] J. Zeil et al., J. Comp. Physiol., 159A,(1986), 801.

[3] P. Kunze, Z. Zellforsch., 82, (1967), 466.

[4] J. Rosenberg et al., Acta Biol. Benrodis, 11, (2000/2001), 53.

[5] J. Zeil and M.M. Al Mutairi, J.Exp. Biol., 199 (1996), 1569. 


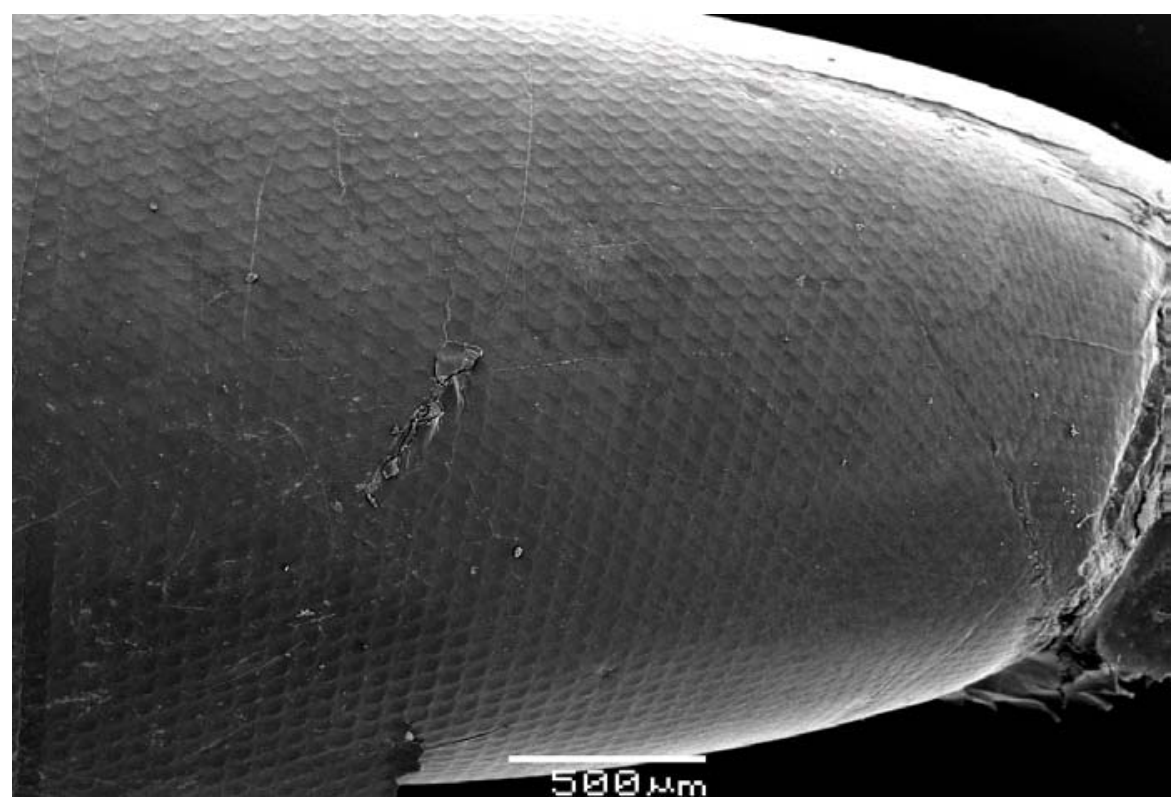

Fig. 1a. A low magnification view of the compound eye surface of Ocypode platytarsus

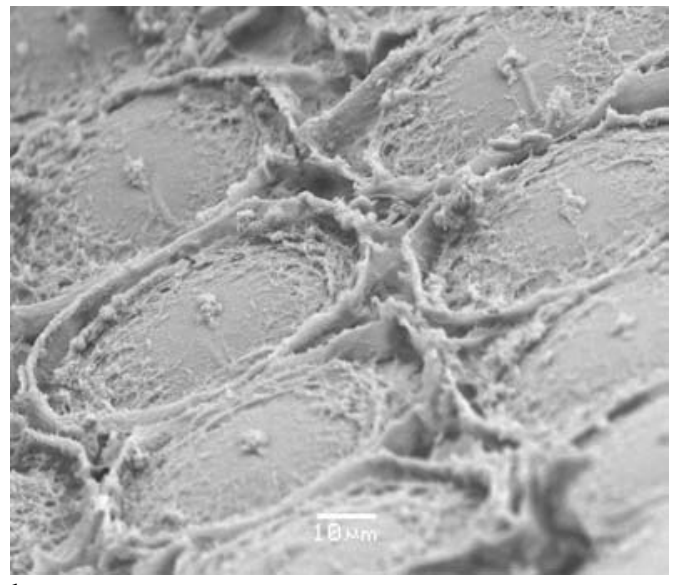

$\mathrm{b}$

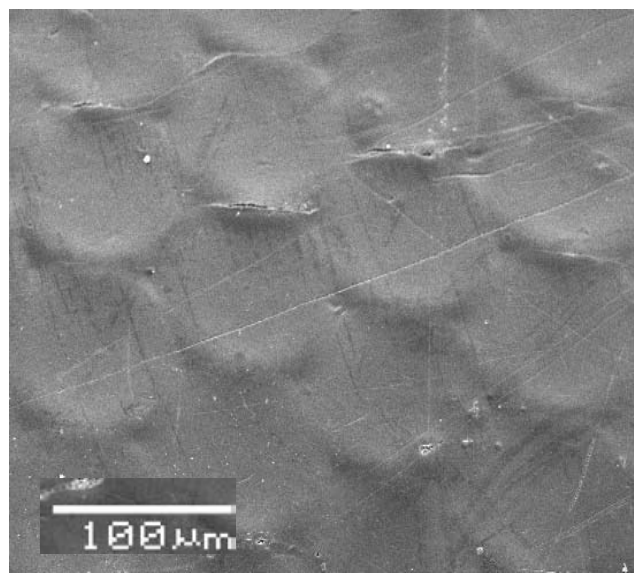

c

Fig. 1b, c. A high magnification view of the compound eye surface of Ocypode platytarsus 